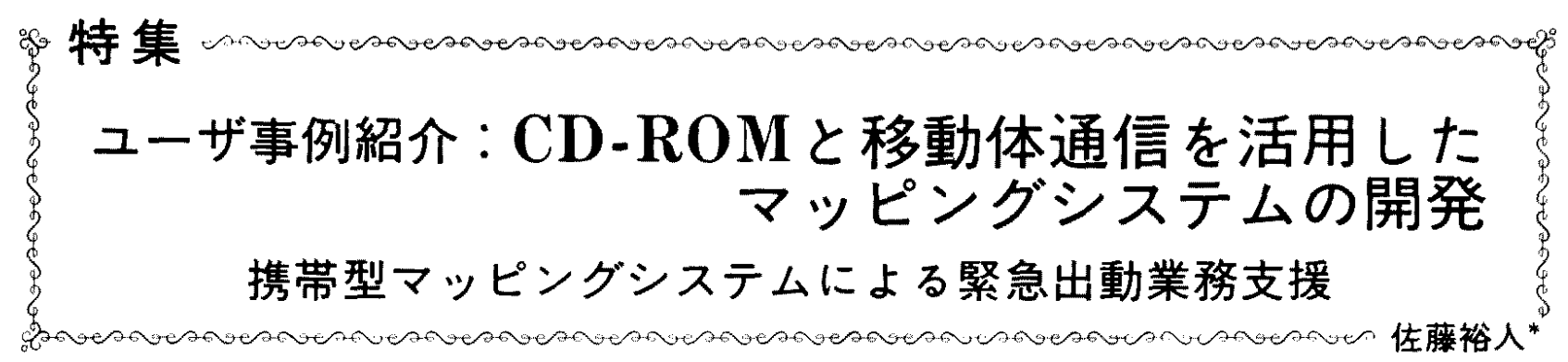

\title{
Special Feature
}

\section{Development of a mobile mapping system using CD-ROM}

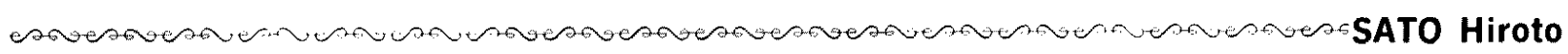

[著者抄録] 東京ガスは利用者情報を活用して緊急保安業務, 設備管理業務, ガス営業活動の最 前線が有効利用できるシステムを開発した。このシステムは，CD-ROMと移動体通信システム，ホ ストコンピュータ上のデータベースを一体として活用することにより，同レベルの情報をべースに 基地と最前線のコミュニケーションを計れるようにして緊急時の出動から到着までの時間短縮，作 業の円滑化，保安レベルの向上を狙っている。外部にデータを持ち出すことに対する機密保持，作 業の進捗状況の管理, 検索機能, 画面描写の高速化, CD-ROMの保守やこのシステムを利用した今 後の展開などを紹介している。

[著者付与キーワード］ＣD-ROM, 移動体通信, マッピングシステム, 検索, 地図, セキュリ ティー

[Author Abstract] Tokyo Gas Co., Ltd. developed a system effective for front lines of emergency security, facility management and gas selling operations utilizing user information. It is an integrated system of CD-ROM, movable communication system and databases loaded on a host computer aiming at shortening of time from troop's turning out at emergency to their reaching accident site, smooth operation and improvement of security level, through communica. tion between front lines and stations based on information. This paper introduces how secret is protected from bringing out of data, how progress in operations is managed, searching capabilities, how image description should be speeded up, maintenance of CD-ROM and future development of this system.

[Keywords by Author] CD-ROM, movable communication, mapping system, searching, map, security

* 東京ガス俳 情報システム部 マッピングセンター（テ 260-91 千葉市美浜区中瀬 2-3）Tel.043 (296) 5737 Tokyo Gas Co., Ltd. Information Systems Department Computer Mapping Center (2-3, Nakase, Mihama-ku, Chiba-shi, 260-91) 


\section{1. は じめに}

昨今, 日本では, RACS, AMTICS, VICS 等社 会的規模の車載情報システムの構築の動きがあ る。

東京ガスにおいても，マッピングデータ，お客 様情報等のホストコンピュータ上のデータべース を緊急保安業務, 設備管理業務, ガス営業活動の 現場の最前線で有効活用できる車載あるいは携带 型の情報システムの構築の要望が強い。

当社ではすでに社内の事務所で利用可能なマッ ピングシステムの構築を完了し，実運用している か、今回, 緊急保安業務において, さらに車両を 含む形の総合保安業務支援システムに発展させ た。

本システムは, 車两と事務所を情報通信ネット ワークで結び，情報の共有化を実現したものであ る。具体的には，車両の中で，事務所と同レベル の情報処理を可能にし，同じ情報をぺースにして， 基地と車两のコミュニケーションを行う。これに より, 緊急時の出動から到着までの時間短縮と作 業の円滑化が達成され, 保安レベルの向上につな がる。

ハードとしては, GPS (Global Positioning System）と CD-ROM を接続したペン PCからな る車載システムと基地側の PCをホストコン ピュータを介して接続, 通信媒体としては, 自動 車電話を用いた移動体通信を使用しているため沉

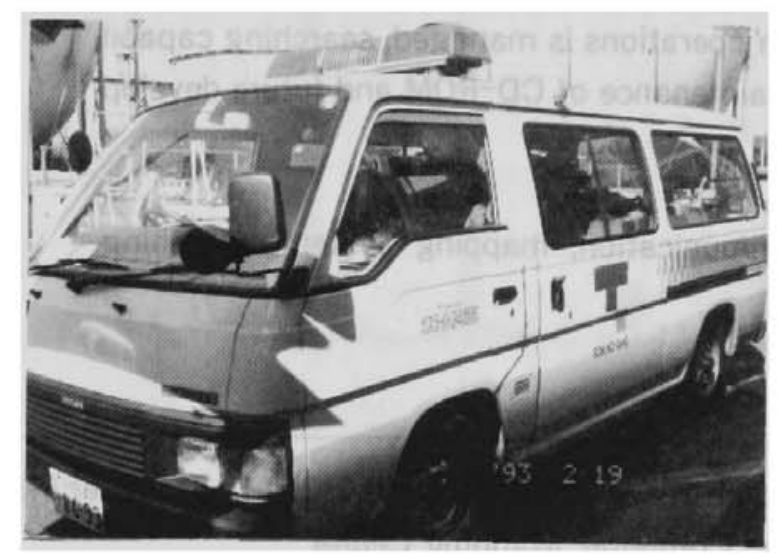

図 1 保安用緊急車両と基地
用性が高く，導入ならびに運用コストも低くおさ えることが可能である。

本システムで実現する手法は, 今後のフィール ド業務の情報化に向けた大きなステップになると 考える。

\section{2. 開発の背景と目的}

東京ガスにおける設備管理業務の中で, 特に事 故, 火災, 災害などの非常時の応急修理対応を行 うのか緊急保安業務である。

緊急保安業務は, 図 1 に示すような保安用緊急 車両と基地の間の連携によって行われる。通常, この連携は, 従来, 図 2 のよjに, 無線による音 声連絡やFAX を用いて行われてきた。

しかしながら、

(1) 緊急処理対応に係る処理時間の增大

(2) FAX 等による伝達情報量の限界

（3) 緊急保安要員等, 保安投資費用の増大 といった問題点があり，これを解決する技術がか ねてから望まれていた。

本システムは，車載 GIS 技術とGPSによるロ ケーションシステム技術を開発することにより， 保安用緊急車両における緊急保安業務を総合的に 支援するものである。

本システムはこのような技術を開発することに より,

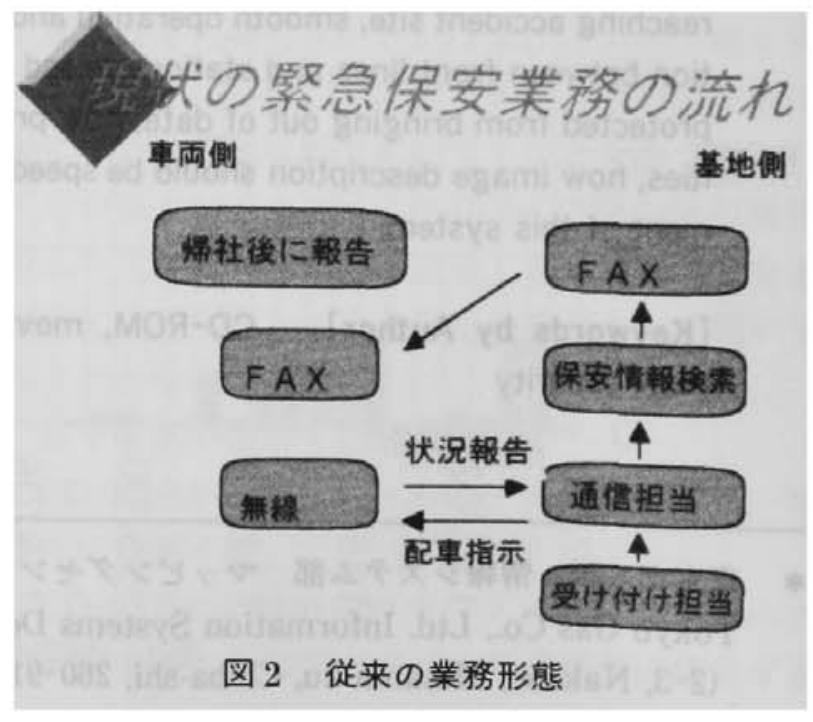


(1) 受け付けから出動までの時間の削減

(2) 受け付け業務の拡大, 担当者間の最新情報の 共有化と車両と基地局間の情報伝達の迅速化, 高度化

等を目的としており，保安の向上，人件費增大の 抑制を図ることを最終目標としている。

\section{3. 開発の経緯}

本システムの開発は以下のような三つのフェー ズに分けて行われた。

\section{1 車載マッピングシステムに必要な基本技 術の確立（フェース゚1）}

本フェーズでは，まず，車両において，「移動体 におけるマッピング情報の利用」を可能とするた めに必要な基本技術の確立を目的として日産自動 車と共同開発した。

\section{1.1 車載コンピュータの取り扱い}

汎用パソコンによる評価システムを試作し, 机 上評価, 現場モニタ一の結果, 操作性・耐久性の 観点から, 車載コンピュー夕に要求される機能仕 様を確定し, 専用の車載コンピュータを試作した。

\section{1. 2 地図データベースの取り扱い}

車載コンピュータによる地図描画を高速に行j ため, 地図データベースの分散データベースを CD-ROMにより構築して車載することにし，ホ ストコンピュータで稼動しているマッピングシス テム (TUMSY) の地図データから CD-ROM 版 データベースの作成を行った。なお, 最新の地図 データペースをホストコンピュータから検索する ことも必要になるため, 移動体通信 (自動車電話) を用いた，ホスト地図データベースアクセス機能 も併せて, 開発した。

\section{1. 3 フィールドテストによる評価}

本フェーズの成果については, 1991年 4 月から 1992年 3 月までの 1 年間, フィールドテストを実 行し, システムの業務適応性と要素技術の妥当性 を確認した。

テストを通じて, 車載コンピュータの操作性の
向上, 低コスト化, 沉用化が実用化に向けた課題 となった。

\section{2 車載マッピングシステムの実用化 (フェーズ2)}

本フェーズは車載マッピングシステムの奉用化 を目的とし，車載コンピュータとして，新たにぺ ンPCを採用し, 操作をすへてペンによる画面 タッチ方法に変更した。

\section{2.1 開発形態と開発内容}

ペン PC を用いた車載マッピングシステムの開 発を1991年 4 月より開始し， 1993年 3 月に完了し た。

また, アプリケーションの汎用性を考慮して, ペンPCのOSとしては, 米国 MICROSOFT 社 の「PEN WINDOWS」を採用した。

\section{2.2 実運用に向けたテスト}

1993年 4 月より，緊急車両10台に図 3 に示すよ うな形でシステムを搭載し，テスト運用を行って いる。テスト結果の評価後, 1993年下期から順次, 搭載台数を拡大し, 3 年間で122台の緊急車両すへ てに搭載する予定である。

\section{2.3 携帯型マッピングシステムへの発展}

この車載マッピングシステムはその後, 携带型 マッピングシステム (TUMSY / BOY) として発 展していき，簡易型マッピング検索装置として他 の業務へも展開していく。

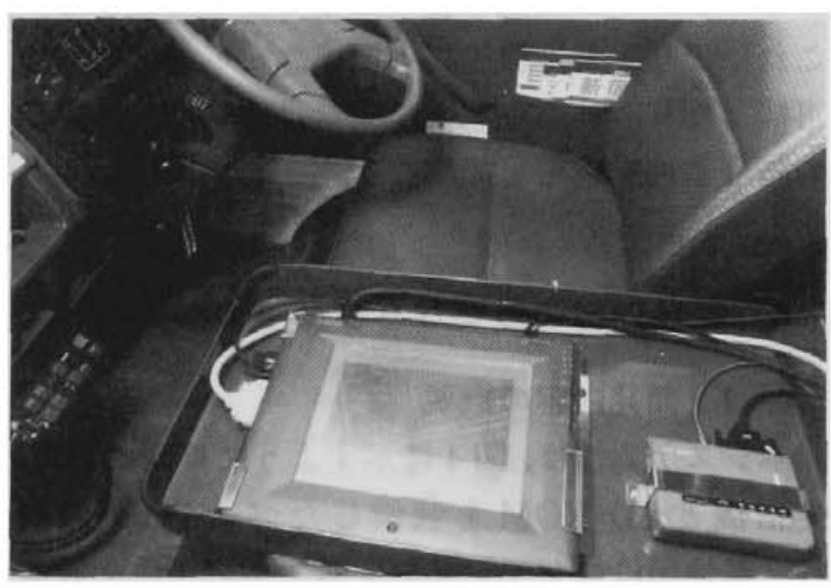

図 3 車載システムの外観写真 
3. 3 ロケーションシステムの開発

$$
\text { (フェーズ 3) }
$$

フェーズ 2 と平行して，GPSを用いたロケー ションシステムの開発を行った。当初は車両の位 置管理機能に絞って開発, 連用を行い, その後, 車載マッピングシステムと連結させ, 将来は携帯 型のロケーションシステムに発展させる。

以下の点を考慮して開発を進める。

\section{3. 1 車載マッピングシステムとの接続}

車両側端末として車載マッピングシステムを使 用し, 車両からの業務報告とロケーションシステ ムを連動させる。これにより, 図面検索, 作業状 態報告, 伝票報告などの報告作業と連動して位置 情報を基地に自動的に送ることが可能となる。

\section{3. 2 設備情報管理システムとの接続}

ロケーションシステムの基地側端末画面上で, 車両の位置と連動して，ガス設備の検索が自動的 にできるようにする。これによク, 複数車両に必 要な情報が自動的に入手可能となり, 基地側の指 令担当の作業が大幅に効率化する。

3. 3. 3 ロケーションシステムの携帯化

携带型マッピングシステムのハードウエアの能 力向上に伴い, ロケーションシステムのソフトウ エアはフェーズ 2 の携帯型マッピングシステムの 上で稼動させることが可能である。つまり, ロケー ションシステムを携带して使用できる。

実際に, 緊急車両の中でも, 特に指令機能を強 化した指令車両については, 将来, 基地側のロケー ションシステム機能を持つ携带 PC を搭載する。 これにより, 基地機能の主要機能が車両上で実現 可能となり, 地震等, 大規模な災害時に, 移動型 の指令基地を運用可能になる。

\section{4. 開発内容の概要ならびにその機能}

\section{1 開発内容の概要}

本システムでは, 図 4 に示すように車両に GPS 受信機と CD-ROM を装備したペン PC を設置 し, 基地局にロケーションシステムの PC を設置 している。この構成により, 移動体通信を介して,
車再，基地局，ホストコンピュータが相互に情報 伝達を行うことができる。

本システムを使用して以下の処理が可能にな る。

\section{2 実現された機能}

車载マッピングンステム, ロケーションシステ ムの開発により実現された機能は以下のとおりで ある。

車載マッピングシステムの機能として,

(1) 車两内における, 地図データベース娭索機能

(2) 作業状況および作業伝票の報告機能

(3) 作業現場状況の画像電送機能

ロケーションシステムの機能として,

(1) 基地における車両の位置, 状態管理機能

(2) 車両と基地の間の双方向コミュニケーション 機能

（3）基地におけるガス設備図面等の保安情報の自 動検索機能

各機能の説明を以下に行う。

\section{2. 1 地図データベース検索機能}

緊急車両が現場に到着してから, 作業員は車載 コンピュータを使用して, 現場作業に必要な最新 のガス設備図面を検索することができる。

（1）地図表示場所の指定方法

最初に表示する地図の場所を指定する方法で, 住所または図面番号によるマニュアル指定, GPS

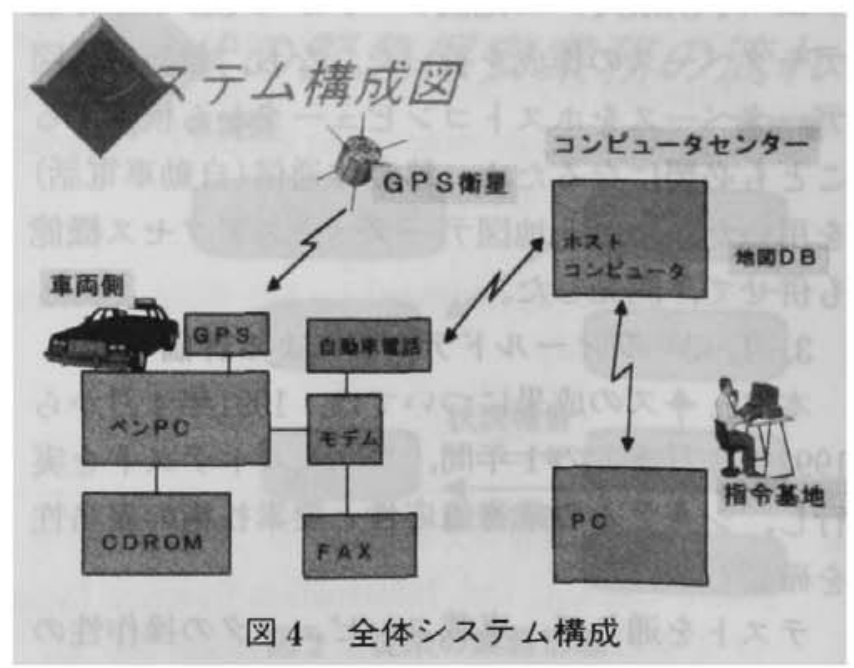


による自動指定方法, 基地端末からの遠隔指定方 法の 3 通りがある。

(a) マニュアル指定

住所検索は区または市名等の行政区名, 町村名 を階層的に画面上に表示したものから選択，丁目 番地号を数字でタイレクト入力することによって 行われる。

(b) 自動指定

GPSによる場所指定は, 画面上の GPS メ ニューを指定することにより, 自動的に行われ, GPSの座標データを取り込み, 現在の車两の位置 が指定される。

(c) 遠隔指定

基地側に設置されたマッピング端末で検索した 場所指定情報が, 自動的に指定した車両の車載端 末に送られる。

いずれの場合もただちに(2)および(3)の画面が表 示される。

通常は, 基地からの遠隔指定により, 現場到着 時には, 車両側で該当図面が自動的に表示されて おり, 表示内容を変更する際に, マニュアル指定 あるいは, 自動指定を使用する。

（2）概略図の表示（図 5 )

指定した地域の周辺の $200 \mathrm{~m}$ 四方の見出し地図 （街区，地名）を画面上に表示する。

(3)で表示する詳細地図の表示範囲を意味する枠
（100 m四方）が画面上に重ね表示されており，枠 が見出し地図の境界に近つくと隣接した地域の地 四を自動的に立ち上げ，表示する。

(3) 詳細地図の表示（図 5)

(2)の枠で指定された地域の地図の上に埋設ガス 管情報を任意の縮尺で, 重ねて表示させる。

スクロール機能ボタンと対応してスムーズに表 示地域全体を任意の方向にスクロールさせること ができる。

埋設ガス管情報はすへて CD-ROM 上にも書き 込まれているが，最新の埋設がス管情報が必要な 場合は自動車電話を利用したデー夕通信によって ホストコンピュータの TUMSY 地図データベー スから受信できる。なおこのホストデータべー スは, 事務所の別の端末から, 常に最新状態にな るよう更新されている。

\section{2. 2 現場状況報告機能}

現場作業の完了後, 作業員は車載コンピュータ 上の簡単な操作によって，現場の作業状況等の報 告を行うことができる。

（1）作業状沉報告（図 6 ）

・図 6 に示すような画面上のボタンを押すことに よって, 定型の報告事項 (動態, 伝票) またはメ モ情報をホストコンピュータに送信することがで きる。

・現場の作業員は画面の地図上にペンで必要事項

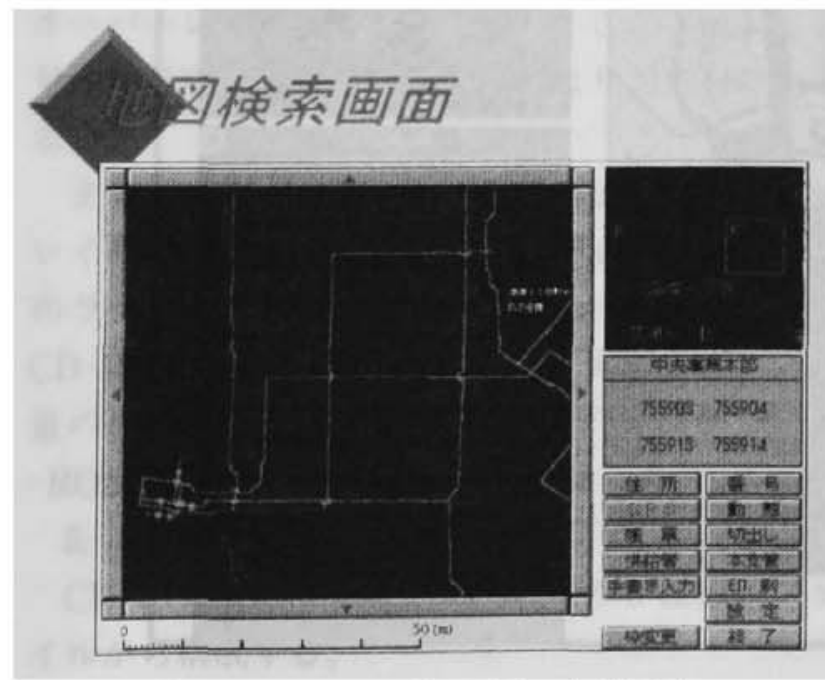

図 5 概略図と詳細地図の表示画面

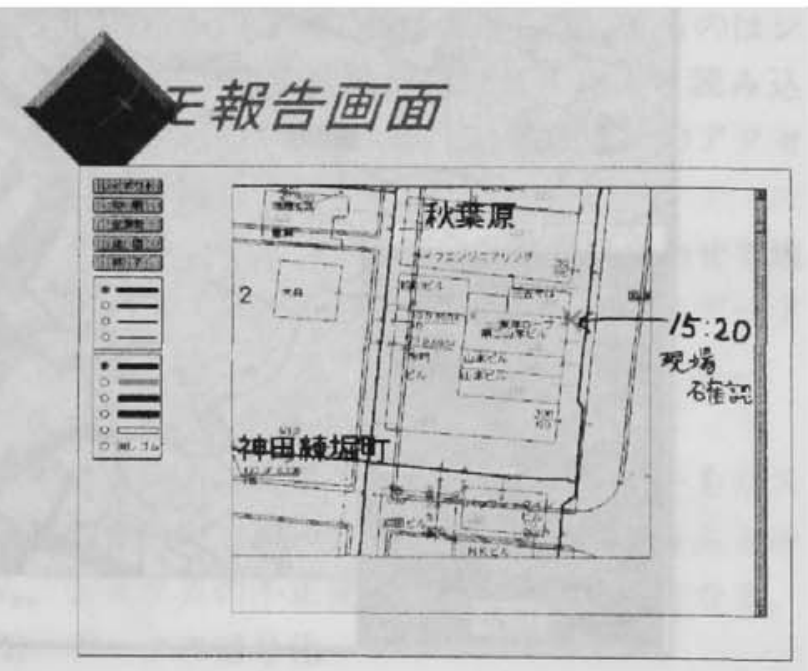

図 6 作業状況報告画面 
を記入し，これをガス設備情報と関連付け保存す ることができる。

・報告された情報についてはホストコンピュータ に接続したマッピング端末にただちに，表示され るとともに, 関連する他システムに連結される。

（2）現場の画像情報の報告

車載コンピュータに接続可能なデジタルカメラ を使用して，現場の状況写真を撮影し，ただちに， 画像を移動体通信によるデー夕通信によってホス トコンピュータに電送し, 基地側のマッピング端 末に表示する。これにより, 現場の正確な情報を 基地側で把握することができ，的確な指示を行う ことができる。

\section{2.3 ロヶーションシステムの機能}

基地側の通信担当は図 7 のロケーションシステ ムの画面上で常時, 全車两の位置と状態ならびに, 受け付け場所を確認でき, 的確な配車指示を行え る。また, 同一画面上で, 車両付近のガス設備情
報の検索, 車两との情報交換を行うことができる。 （1）車两の現在位置と状態の自動表示 基地の管轄エリア全体を表示した地図を表示し た画面上に全車両の位置をマーク表示する。車両 の移動にともなってあるインターパルでこの マークも自動的に移動する。受け付け担当が受け 付けた場所もこの上に表示される。

(2) 車両付近のガス設備情報の自動検索 画面上の車両の中から指定された車両につい て, 付近のガス設備図面情報を自動的に検索する。 これは, 車両の位置座標をキーとして，ホストコ ンピュータの地図データベースサーバにアクセス する形で実現される。

(3) 車再との双方向のメッセージ通信 車两と基地側端末との間で, デー夕通信による 双方向のメッセージのやり取りを行う。具体的に は, 画面上の車两付近に開くウインドウ（空）を 通して, 電子メールの交換を行う。

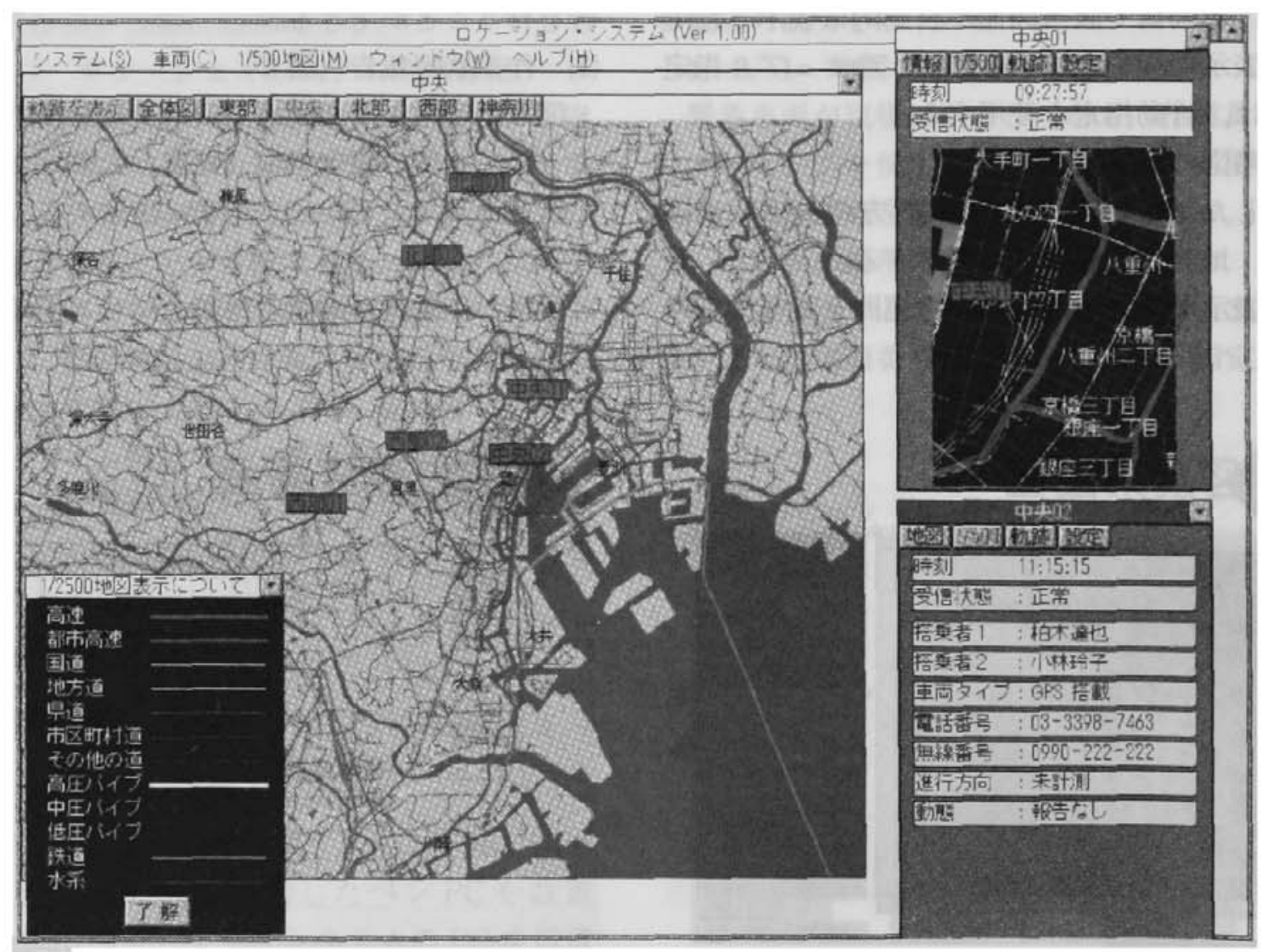

図 7 ロケーションシステムの画面 


\section{5. 具体的な開発内容}

\section{1 操作設計}

緊急車雨の中での車載システムの操作性は，本 システムの中で重要な要秦となる。本システムで は，緊急保安業務という緊張状態において，しか も車両の中でシステム操作を容易に行之るような ユーザインタフェースの設計を行った。

さらに同一システムを携带使用する可能性か ら，車而とオフィスの両方で使用する事を想定し， 表示範囲，項目などの画面構成を容易にカスタマ イズできるような汎用化を行った。

\section{2 CD-ROM 地図データベース設計}

本システムでは，移動側からホストコンピュー タの地図データベースをアクセスする。地図デー タベースは大容量であるという特徵があり，また， 保安業務という性格から，常に最新の情報を必要 とする。

以上から，CD-ROM と移動体通信を組み合わ せた地図データベースアクセス方式を新たに開発 した。以下に，その具体的取り扱いを示す。

\section{2. 1 地図データの概要}

東京ガスの地図デー夕は，約 3 万枚の地図（小

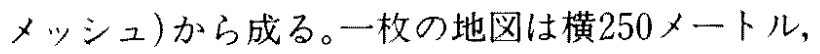
縦350メートルのメッシュ単位のオーバーレイに 分割されており，それぞれ固有のメッシュ番号， オーバーレイ番号で管理される。このメッシュ番 号は国家座標系の座標と計算により対応付けられ る。

また，データのアクセスはメッシュ，オーバー レイ単位でランダムに行うことが必要である。こ のランダムアクセスに対応して，指定データの CD-ROM 内の所在位置を素早く見つけ出し，大 量のデー夕を高速で転送できるデ一夕構造（CD -ROM 地図フォーマット）を設計した。

\section{2. 2 データの構造}

CD-ROM 内の地図デー夕は次の 3 種類のファ イルから構成する。

(1) 住所ファイル
住所検索時に使用する索引データで，東京がス の全供給エリア内の市名（区名）町名，番地，号 レコードから構成され，各レコードにはUとつの 座標が対応付けられ，概略地図または詳細地図に おいて中央に表示する場所を特定する。

(2) データファイル

$1 / 500$ の精度の道路, 地名, 導管情報, 供給管 情報などのマッピングデータの本体部分であり， 大メッシュ（小メッシュが100枚分）単位の連続 ファイルの形で CD-ROM 上に割り付叮られる。 東京ガス全供給工リア全体の1/3について約 $500 \mathrm{MB}$ 使用する。

（3） CD 管理情報ファイル

CD-ROM 内の各データファイルの格納地域, 作成日などの管理情報を持つ。

\section{2.3 高速描画のための工夫}

高速描画対策は，基本的には「CD-ROM へのア クセス I $/ O$ 回数を極力減らす」との観点で検討 し，以下の内容を盛り込んだ。

以下に CD-ROM 内の地図データベースアクセ スを高速化するための対策を記す。

(1) 隣接した周辺メッシュ(8枚分)の相対レコー ド番号を上記レコード内に書き込んでおく。こ れにより，周辺へのスクロール速度を向上させ る。

(2) 相对レコード番号はデータファイル内の位置 に对応できるように索引を持つ。

（3）管理情報のなかで随時使用していくものはシ ステム起動時に管理情報ファイルより読み込

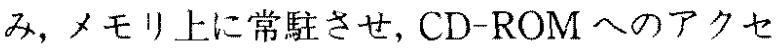
又回数を減らす。

(4) 車載コンピュータの表示分解能に合わせて地 図データファイル内のショートベクトルデータ を削除し、データファイル容量を圧縮する。

\section{2.4 セキュリティー対策}

本システムは，車両上で使用され，しかもガス 設備情報という機密上，重要な情報を扱うことか ら，システムの不正使用への対策が必要となる。

(1) データの暗号化

セキュリティーの観点から CD-ROM データ 
ファイルはすべて暗号化した。これにより，CD -ROMのみが，紛失した場合に対応する。

(2) パスワードによるアクセス制限

検索アプリケーションの起動にあたりパスワー ド入力を義務付けた。これにより, 正規の操作者 以外の不正使用，または車載システム全体機器あ るいは車画の盗難等の不测の事故に対応する。

（3） ログ情報の取得

正規の操作者においても不正使用を防止するた め, システムの起動から終了に至るまでの操作履 歴を記録し、ログファイルとして保存している。

\section{2. 5 埋設ガス管データの取り扱い}

地図データの内, 埋設ガス管に関するデータは, 「CD-ROM 上に書き込まれているデー多」と「通 信回線を使ってホストから転送するデー夕」があ ク，どちらも本支管，バルブ等の本支管設備，供 給管を含む同一フォーマットのデー夕構造とし た。

これにより，経時変化が少なく基本的なデー夕 は CD-ROM 上のデータを利用することによっ て，通信回線不通時への対応も可能となる。

「通信回線を通じて転送するデー夕」は, 詳細 地図の表示区域 $(100 \mathrm{~m}$ 四方) が決定した時点，も しくは，操作者が指示した時点で送信要求をホス トコンピュータ側に送出し，これに対応して，ホ ストコンピュータ上のデータベースサーバが表示 区域内に限定して, 地図データベースを切り出し, 順次データが転送される。

また，将来，指定供給管に接続する需要家の情 報（文字数值情報）についてもホス卜側で検索・ 加工後, 地図デー夕の属性情報として転送される 予定である。

\section{3 通信処理}

本システムは, クライアントサーバモデルで構 成され，その間の通信は，移動局，通信サーバ, データベースサーバ間で連携して行われる。

フェーズ 1 では，通信処理開発の容易性から， 通信サーバをパソコンを使用した基地局上に構築 し，ホストコンピュータ(VAX) 上のデータベー
スサーバとはネットワーク（LAN）接続した。

フェーズ2では, 对象車雨台数の今後の増加に 対応すへく，通信サ一バをホストコンピュータ (VAX) 上のソフトウエア処理に置き換えた。以 下に具体的な通信処理の内容を示寸。

5. 3. 1 移動局, 通信サーバ, データベース サーバ間の通信処理

移動局と通信サーパの間は自動車電話回線およ び公衆回線上でモデム間のエラーフリ一機能を利 用したファイル転送を行う。これにより，アプリ ケーションレベルの通信プロトコルは, 非常に簡 素化された。なお，フェーズ2において，モデム のエラーフリー機能としては,パソコン通信など で，広く普及しているMNPクラス10を採用し た。

\section{3. 2 転送情報}

基本的な通信パターンでは，移動局から情報を 転送し，これに对応してデータぺースサーバから 処理結果が転送される。なお，データペースサー バから処理結果が割り込みの形で転送されるパ ターンもある。

（1）移動局からの通信情報

移動局から転送される情報は次の 4 種類であ る。すべて，GPSから自動取得される現在位置と 時間とともに転送される。

（a） 図面切出し用エリアとレイヤ一の指定情報

これは，ホスト側のマッピングデータベースを 検索する場合のキーとなる位置情報である。この データをもとにホストコンピュータ上の地罒デー タベースサーバが，任意の場所を検索し，送信用 切り出しファイルを作成する。

(b) 動態報告内容

車の作業状態（到着, 落成, 移動, 出動) であ ク，数字でコード化された形で転送される。

(c) 作業報告内容

緊急出動にかかる応急修理の報告内容である。 通常の報告書の項目をコード化したものである。

(d) デジタルカメラから取得した画像情報

デジタルカメラで撮影した, 現場のカラ一静止 画像情報である。 
(2) データベースサーバ側処理結果

(a) $100 \mathrm{~m}$ 四方の切出し地図情報

データペースサーバが管理するマッピングデー タベースから任意の $100 \mathrm{~m}$ 四方に切り出された図 形データである。CD-ROM データベースと同一 フォーマットのバイナリーファイルであり, CD -ROM と同様に圧縮, 暗号化されている。

(b) 各種報告処理結果

動態報告, 伝票報告の処理結果であり, 報告工 ラーなどの情報を含む。

\section{4 ハードウェア設計}

フェーズ 2 以降の実用システムで使用する車載 ハードウエア構成を示す。ここでは, 車載コン ピュー夕, 操作スイッチ, 表示装置を一台のペン $\mathrm{PC}$ で実現し、これにモデム・CD-ROM ドライブ を接続した。

\section{4. 1 ペン $\mathrm{PC}$ 本体}

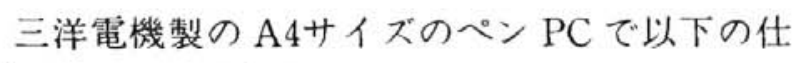
様のパソコンである。

(1) $\mathrm{CPU}$ : インテル80386SX

(2) メインメモリー：5MB 装備(最大 $20 \mathrm{MB}$ )

(3) RS232C 2 ポート装備

(4) SCSI 装備

\section{4.2 モデム}

公衆回線と自動車電話回線対応デー夕通信モデ ム兼FAX モデムとして使用可能なものを使用し た。

(1) メガソフト社製「スターFAX」

(2) デー夕通信: MNP10对応, 実効速度 4800 BPS 程度

(3) FAX 通信: G3FAX 対応

(4) ローカル FAX 機能付き

5. 4. 3 CD-ROM ドライブュニット 三洋電機製車載型 CD-ROM ドライブ

\section{4. 4 記録装置}

フェーズ1の FAXを使用し, モデムのローカ ルFAX 機能を使用して印刷装置とした。

また, FAX モデムを用いて, 回線経由で一般の G $3 F A X$ に直接出力することも可能である。

\section{6. 運用}

6. 1 ハードウェア構成

図 8 に全体のハードウエア構成を小す。 各指令基地にはロケーションシステム用の PC を 配置し、これらはホストコンピュータ (VAX) と 専用回線または公衆回線でネットワーク接続す る。また, 車再上にはへン PCによる車載マッピン グシステムを搭載し、これらはホストコンピュー 夕と公衆回線で接続する。

以下（図 9 ) にシステム化後の業務フローを記 す。

\section{2 保守・運用体制}

\section{2.1 保守運用体制の整備}

緊急保安業務は24時閒体制で行われる。各 PC のシステム的な状態は，ホストコンピュータ上で 監視されており、システムトラブル等への対応は, ホストコンピュータの設置されている幕張ビル内 のネットワークサポートセンターで，24時間体制 で行われる。

また, PC 側のソフトウエアのメンテナンスは, ホストコンピュータからの遠隔操作により行うこ とが可能である。

\section{2. 2 ソフトの保守}

TUMSY /BOY は使用形態や用途に応じて, 画面レイアウトや機能を容易に再構成できるよう に設計した。このようなカスタマイズはメニュー

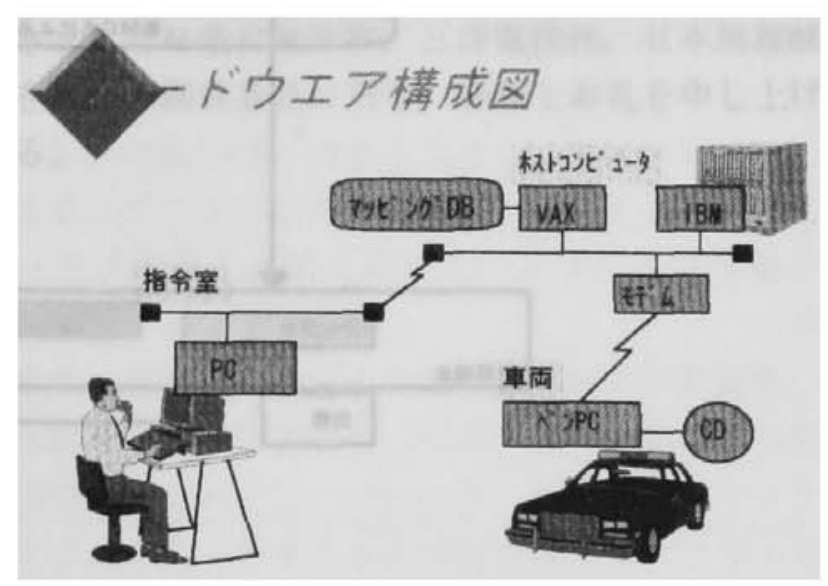

図 8 全体のハードウェア構成 
から必要な項目を選択することで実現している。

\section{2. 3 CD-ROM の保守}

TUMSY /BOY は, CD-ROMに登録したデー 夕を半年に 1 回の割合で更新する。デー夕更新に あたっては, 新たに作成した CD-ROMを TUMSY / BOY 導入箇所に配布する。この CD -ROMには, 最新版の TUMSY / BOY アプリ ケーションソフトウエアを登録し, CD-ROM 交 換時にシステムが自動的にバージョンアップされ る手法を開発した。

\section{7. 他業務への展開}

本システムの技術で特に携帯型マッピングシス テム(TUMSY / BOY)の技術は最近, 緊急保安 業務のみならず簡易型のマッピング情報検索端末 として他業務へも展開している。

\section{1 支社店口での利用}

顧客からの埋設管調查依頼に対応する支社の店
ロに本ンステムを設置している。平成 6 年 9 月時 点で 5 支社に導人しており，1支社あたり月平均 500 件のガス設備情報の検索に利用している。今後 順次本システムを必要とする支社店口への導入を 図っていく子定である。

\section{2 工事会社での活用}

平成 6 年 4 月から営業設備関連工事を委託して いる工事会社に本システムの導入を開始した。9 月現在, 約 50 所の工事会社において使用してお $\eta, 1$ 工事会社当り月平均 120 件のガス設備情報の 検索に利用している。

今後 3 年間で全工事会社の 260 事業所入導入す る子定である。

\section{8. 今後の展開}

本システムの中の携帯型マッピングンステム （TUMSY／BOY）の技術を応用した今後の展 開の考え方について以下に記す。

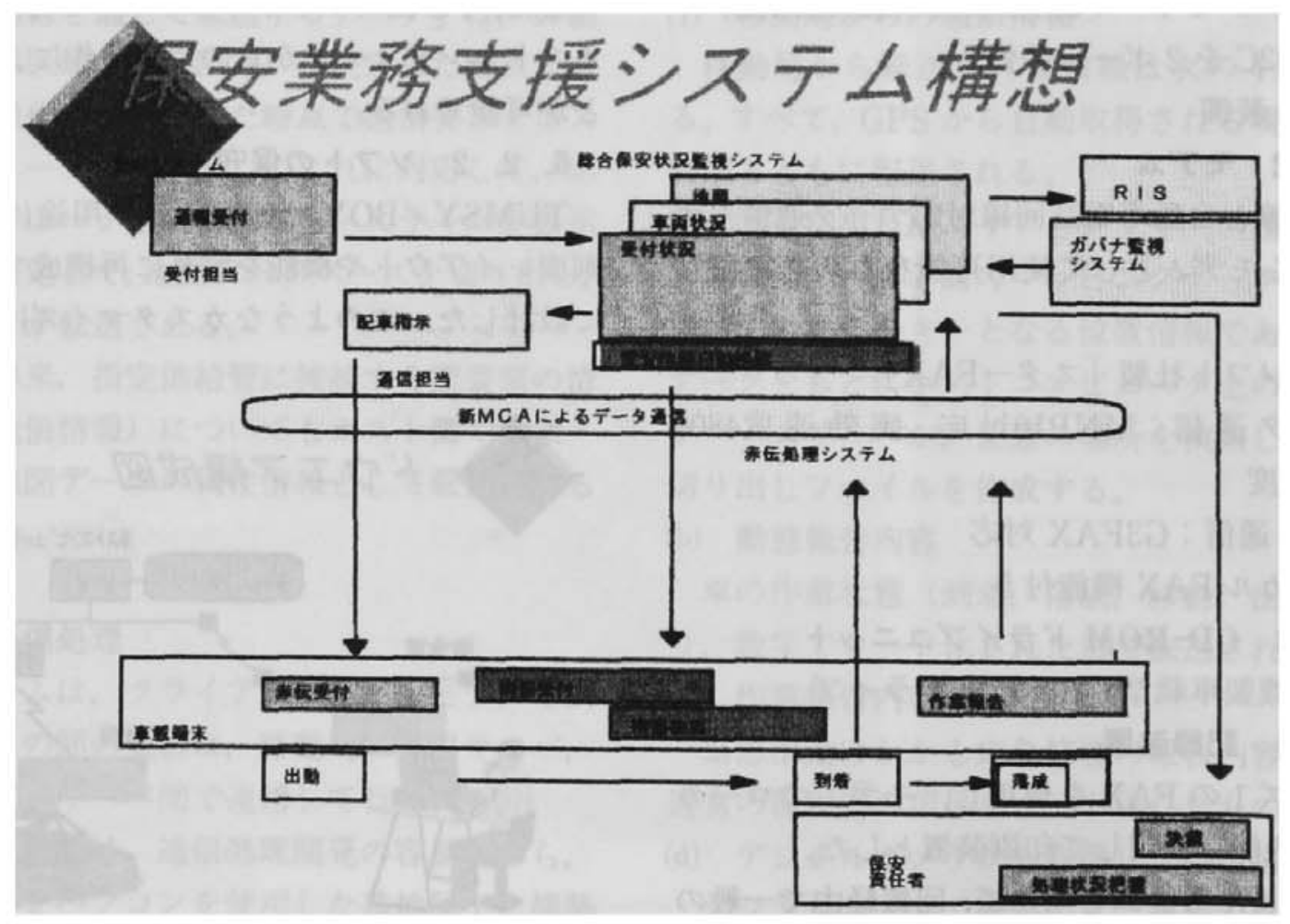

図 9 システム化後の業務フロー 
TUMSY $/$ BOY は小型・軽量で携带性に優れ， ペンPCを用いた容易な操作環境を有している。 また，多様な業務に適用できるよう沉用的に設計 しており，特定用途向き機能を簡単に付加するこ とができる柔軟なカスタマイズ能力を持ってい る。

考えられる利用分野を以下に列挙する。

(1) 営業関連での携帶利用

・マーケティング

・プレゼンテーション

・営業戦略の立案

（2）工事現場などでの携带利用

・野帳として

・簡易測量, 簡易設計

・各種情報検索, 情報伝達ツールとして

(3) その他

·道路管理

·交通情報管理

・現場検証など

このように応用分野を広げるためには解決すべ き次のような課題がある。

\section{1 利用データの拡充}

本システムの中の車載システムは移動体通信を 用いて，ホストコンピュータ $(\mathrm{VAX})$ との双方向 通信機能を持つ。

このホストコンピュータを顧客情報等を管理す る他のホストコンピュータ (IBM 等) への通信 ゲートウェイとして利用し, 顧客のガス使用状況, メータ状況などの最新情報を地図とともに，現場 で利用可能にする。

\section{2 CD-ROM 収録情報の拡充}

現在，CD-ROMにはマッピングデータベース
の中の基本情報のみ收錄してあるが,ささらに以下 のようなイメージ情報等の収録に拡大していく。

\subsection{1 詳細図面などのイメージ情報}

地下街, 高層ビル等の重要設備の内部のガス設 備に関する四面を収録する。

\section{2. 2 設備外観写真などのイメージ情報}

ガバナ，バルブ等の設備の外観写真を収録し， 点検作業老支搤する。

現在，これらの情報は，本の形で車載しており， CD-ROM 化することにより，製本費用，搭載又 ペース等が効率化する。

\section{3 携帯化}

緊急保安業務は，最終的には，工事現場など， 車両の外で行われる。したがって，車載システム は究極的には携帯使用が望ましい。

現在，フェーズ2のペン PCを携带して車両の 外で使用できるようにすることを検討している。

\section{9.おわりに}

本システムは，移動体と事務所で連携して行わ れる業務処理の支援システムとして応用範囲が広 いものといえる。

本システムで示した手法は，基礎技術の点では 確立されているものの，まだ実績の面ではこれか らであるが，今後，本格的運用に向けて努力して いきたい。

最後に本システムの構筑にあたりご協力いただ きました日産自動車(侏)，三洋電機(侏)，日本無線(侏) をはじめ関係各社に対し，感謝とお礼を申し上げ る。 